\title{
Selection of prime mover to meet heating demand of a single effect absorption chiller based on laws of thermodynamics
}

\author{
M. Mohammadian Korouyeh ${ }^{1} \cdot$ M. H. Saidi ${ }^{2}$ M. Najafi ${ }^{1}$ C. Aghanajafi $^{3}$
}

Received: 29 April 2020 / Accepted: 21 December 2020 / Published online: 11 January 2021

(C) The Author(s) 2021 OPEN

\begin{abstract}
In this study the first and the second laws of thermodynamics are evaluated for a single effect absorption chiller. Entropy generation and COP are selected as the objective functions and their variations are studied by varying the generator temperature for various condensing temperatures. For this purpose, the enthalpy and the entropy data of the superheated steam, saturated steam and the saturated water are formulated in the mathematical equations. Also to provide the required steam of generator, prime mover in the form of internal combustion engine is applied and its partial load conditions are analyzed. A residential tower is considered as the case study for selecting the proper prime mover capacity. The number of prime movers is estimated based on the required heating power of the generator steam for each partial load. It is seen, the entropy generation would be decreased rapidly by increasing the generator temperature and after a while, the entropy generation would be approximately constant. The optimum entropy generation for each condensing temperature and the generator temperature may be decreased by increasing the evaporator temperature. It is deduced that COP is increased rapidly by increasing the generator temperature but in the following, the COP will be constant. The maximum amount of COP is decreased by increasing the condensing temperature. Also the COP is increased by increasing evaporator temperature for a certain generator and condensing temperatures.
\end{abstract}

Keywords Single effect absorption chiller · Prime mover · Entropy generation · Generator temperature · COP

\begin{tabular}{ll}
\multicolumn{2}{l}{ List of symbols } \\
CCHP & Combined cooling, heating and power \\
CFC & Chlorofluorocarbon \\
COP & Coefficient of performance \\
$\dot{E}$ & Electrical power $(\mathrm{kW})$ \\
$\mathrm{h}$ & Enthalpy $(\mathrm{kJ} / \mathrm{kg})$ \\
$\mathrm{hr}$ & Hour \\
$\mathrm{LHV}$ & Low heat value $(\mathrm{kJ} / \mathrm{kg})$ \\
$\dot{\mathrm{m}}$ & Mass flow rate $(\mathrm{kg} / \mathrm{s})$ \\
$\mathrm{p}$ & Pressure $(\mathrm{kpa})$ \\
$\dot{\mathrm{Q}}$ & Heat power $(\mathrm{kW})$ \\
$\mathrm{s}$ & Specific entropy $(\mathrm{kJ} / \mathrm{kg} \mathrm{K})$ \\
$\mathrm{S}$ & Entropy generation $(\mathrm{kW} / \mathrm{K})$ \\
$\mathrm{T}$ & Temperature $(\mathrm{C})$
\end{tabular}

$\begin{array}{ll}\dot{W} & \text { Working power }(\mathrm{kW}) \\ \mathrm{X} & \text { Solution concentration }\end{array}$

Greek letters

$\varepsilon \quad$ Effectiveness

$\eta \quad$ Efficiency

Subscripts

a Absorber

c Condenser

CHW Chilled water

CTW Cooling tower water

e Evaporator

ev. Evaporation

Ex. Exhaust

$f \quad$ Saturated and subcooled

C. Aghanajafi, C_Aghanajafi@yahoo.com | 'Department of Mechanical Engineering, Tehran Science and Research Branch, Islamic Azad University, Tehran, Iran. ${ }^{2}$ Center of Excellence in Energy Conversion (CEEC), School of Mechanical Engineering, Sharif University of Technology, P. O. Box 11155-9567, Tehran, Iran. ${ }^{3}$ School of Mechanical Engineering, K. N. Toosi University of Technology, Tehran, Iran. 


$\begin{array}{ll}\text { g } & \text { Generator } \\ \text { gen } & \text { Generation } \\ \text { HS } & \text { Superheated } \\ \text { nom } & \text { Nominal } \\ \text { p } & \text { Pump } \\ \text { PL } & \text { Partial load } \\ \text { PM } & \text { Prime mover } \\ \mathrm{r} & \text { Refrigerant } \\ \text { s } & \text { Solution } \\ \text { SS } & \text { Strong solution } \\ \text { WJ } & \text { Water jacket } \\ \text { WS } & \text { Weak solution }\end{array}$

\section{Introduction}

CCHP systems are known as the facilities in which produces cooling, heating and power simultaneously through recovering waste heat of prime movers such as internal combustion engines, gas turbines etc. CCHP systems also attract attentions due to environmentally friendly compared to the other conventional systems [1, 2]. Also absorption chillers may be applied as cooling system since they are CFC free [3]. These chillers need low energy that may be provided by the solar energy or waste heat which is extracted from the prime movers. Avanessian et al. [4] evaluated a single effect absorption chiller from the energy, exergy and the economical point of view. Roman et al. [5] investigated on the selection of type of the prime mover and absorption chiller in CCHP systems. They studied the energy consumption, economical and emission parameters. They concluded that emission saving for carbon would be about $9 \%$ and the primary energy consumption saving can be reached till $8 \%$. Fong and Lee [6] studied a high rise office building in Hong Kong and used internal combustion engine beside absorption chiller to provide cooling and heating demand of the building. They compared energy consumption of their proposed system with the conventional system in which uses electrical power. Their study showed that the energy consumption reduction would be about 10.9\%. Karimi and Sayyadi [7] studied a Stirling engine beside an absorption chiller. They evaluated primary energy saving, $\mathrm{Co} 2$ emission reduction and the annual total cost. They found that in extremely hot and humid weather, Stirling-CCHP system is not recommended. Ünal et al. [8] proposed a linear optimization model to minimize maintenance cost. The optimization procedure was held by comparing four different kinds of prime movers for three different load conditions of an industrial facility. They showed that, tri-generation is more cost effective than the separate production. Chahartaghi and Alizadeh [9] studied a CCHP system in which its prime mover was PEM fuel cell. The objective functions were energy, exergy and fuel energy saving. Their proposed model was compared to the conventional energy supply systems and the fuel energy saving ratio was calculated to about $45 \%$. Eisavi et al. [10] used solar energy beside Rankine cycle and absorption chiller as CCHP system. They evaluated the energy and the exergy of the system. Ebrahimi and Keshavarz [11] studied CCHP system for various climate conditions of Iran. They selected absorption chiller as cooling system and evaluated the size of prime mover for each climate condition. Mohammadi and Ameri [12] studied a prime mover beside absorption chiller. They evaluated ambient conditions effects on the proposed system performance. Al-Sulaiman et al. [13] used parabolic solar collector, Rankine cycle and the absorption chiller as a CCHP system. They studied the effect of pump inlet temperature and the inlet pressure of the turbine on the performance of the proposed system. Maindment and Tozer [14] used CCHP system for a supermarket that the prime mover was gas turbine and cooling system was absorption chiller. They compared gas turbine and internal combustion engine. They showed that CCHP energy consumption is lower than the energy usage of the conventional systems. Samanta and Basu [15] analyzed a single effect absorption chiller with heat exchanger in refrigerant side. They found that absorber has dominant role in any increase in entropy generation. Myat et al. [16] analyzed performance of an absorption chiller using an entropy generation analysis. They found that overall entropy generation is $41 \%$ for the generator, $10 \%$ for the condenser, $30 \%$ for the evaporator and about $19 \%$ for the absorber. Ren et al. [17] analyzed an absorption chiller using the Matlab software for thermodynamic analysis. They found COP could be improved by increasing the temperature of hot water or chilled water properly.

In the current study a single effect absorption chiller is applied and the assumptions are considered in which chiller operates properly. The first and the second laws of thermodynamic are evaluated for each part of chiller. COP and the entropy generation are selected as objective functions and they are studied to find their optimum situation by considering permissible concentration range of weak and strong solutions. To evaluate enthalpy and entropy of water, in the saturated and superheated stats, its thermodynamic data is formulated by applying genetic algorithm and by minimizing the error between calculated and thermodynamic data. The COP variations and the entropy generation variations is studied by varying generator temperature in various evaporator temperatures. To meet heating demand of generator, prime mover in the form of internal combustion engine is applied. Since this prime mover does not operate in the full load situation, then its partial load operation is modeled to evaluate the waste heating and the extracted power for each partial load and 
the proper number of prime movers will be calculated in the various partial loads.

\section{Mathematical model}

In this study, a single effect absorption chiller is considered which is shown in the Fig. 1. In the chiller, energy demand of the generator $\left(Q_{g}\right)$ may be supplied by the water steam and the heating energy is absorbed through the evaporator $\left(Q_{e}\right)$ from the low temperature heat source and may be transferred to a high temperature heat source by the condenser $\left(Q_{c}\right)$.

In the absorption chiller, the $\mathrm{LiBr}$ and the water are used as the absorber and the refrigerant respectively. Outlet solution of the generator is known as the strong solution due to high $\mathrm{LiBr}$ content and outlet solution of the absorber is called weak solution due to low $\mathrm{LiBr}$.

Following assumptions are considered to evaluate the absorption chiller:

1. Chiller operates in the steady state.

2. The temperature of the outlet solution from the absorber (state 1) is equal to the outlet water temperature of the condenser (state 8).
3. Solution pump does not effect on the solution temperature $\left(T_{1}=T_{2}\right)$.

4. Fluid flows through the expansion valves are isenthalpic.

5. Concentration of $\mathrm{LiBr}$ free solution equals to zero $\left(X_{7}=X_{8}=X_{9}=X_{10}=0\right)$.

6. Friction losses are ignorable.

7. Pressure drop and heat loss in the components of the system were not considered [17].

Solution concentration should be in the range of 0.5 to 0.65 [18]. For the strong and weak solutions, this quantity may be calculated from the Eqs. (1) and (2) respectively [18].

$X_{i}=\frac{49.04+1.125 T_{a}-T_{e}}{134.65+0.47 T_{a}} \quad$ strong solution

$X_{j}=\frac{49.04+1.125 T_{g}-T_{c}}{134.65+0.47 T_{g}} \quad$ weak solution

Concentration of the weak and the strong solutions are defined as Eqs. (3) and (4).

Fig. 1 Absorption chiller cycle

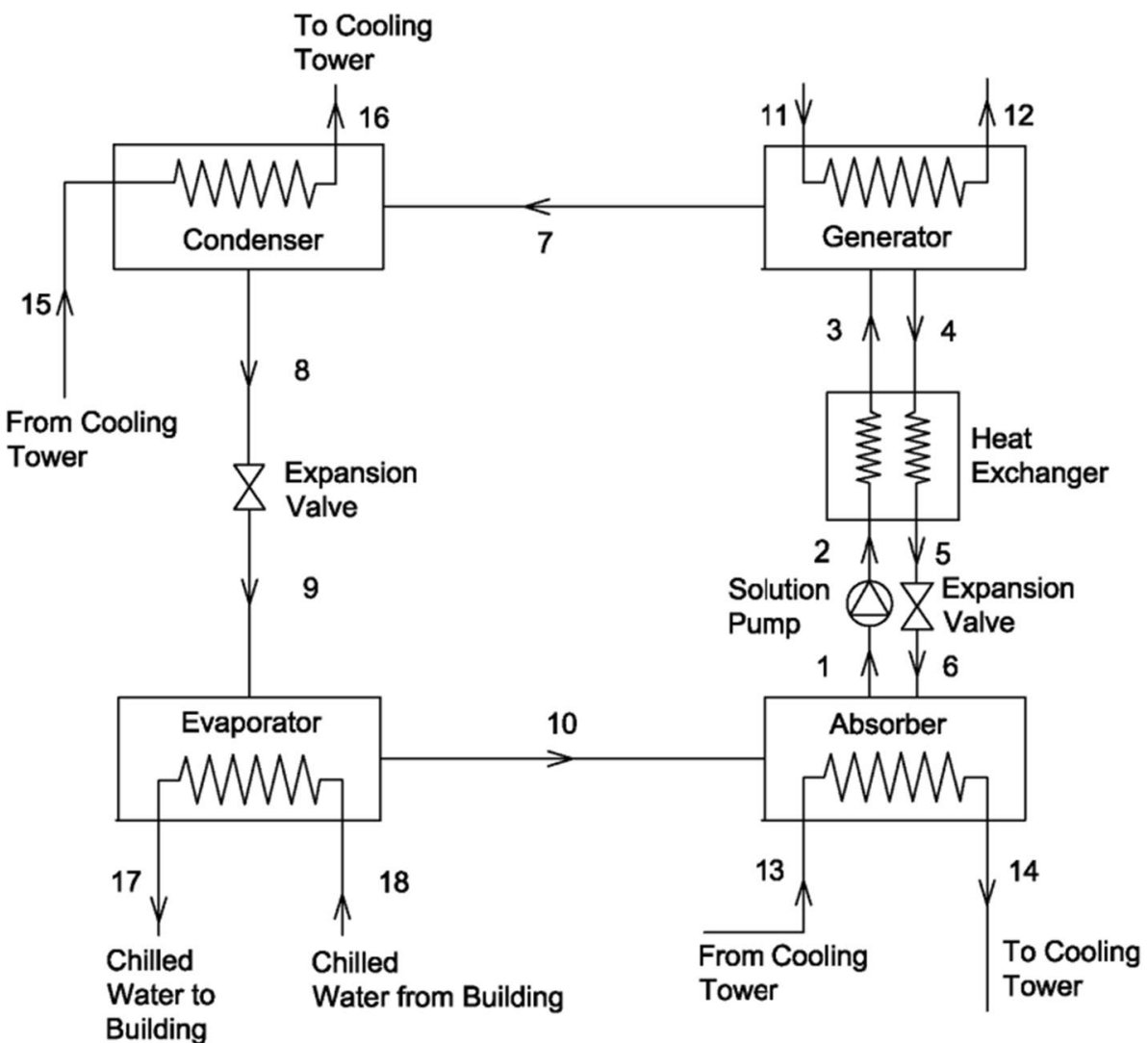


$\mathrm{X}_{\mathrm{ws}}=\frac{\dot{\mathrm{m}}_{\mathrm{LiBr}}}{\dot{\mathrm{m}}_{\mathrm{ws}}}$

$\mathrm{X}_{\mathrm{ss}}=\frac{\dot{\mathrm{m}}_{\mathrm{LiBr}}}{\dot{\mathrm{m}}_{\mathrm{ss}}}$

Equations (5) and (6) may be resulted from the mass conservation law [15].

$\dot{\mathrm{m}}_{\mathrm{ss}}=\dot{\mathrm{m}}_{\mathrm{r}}+\dot{\mathrm{m}}_{\mathrm{ws}}$

$\dot{\mathrm{m}}_{\mathrm{ss}} \mathrm{X}_{\mathrm{ss}}=\dot{\mathrm{m}}_{\mathrm{ws}} \mathrm{X}_{\mathrm{ws}}$

By taking into account Eqs. (5) and (6), the mass flow rate of weak and strong solution is given by:

$\dot{\mathrm{m}}_{\mathrm{ss}}=\frac{\mathrm{X}_{\mathrm{ws}}}{\mathrm{X}_{\mathrm{ws}}-\mathrm{X}_{\mathrm{ss}}} \dot{\mathrm{m}}_{\mathrm{r}}$

$\dot{\mathrm{m}}_{\mathrm{ws}}=\frac{\mathrm{X}_{\mathrm{ss}}}{\mathrm{X}_{\mathrm{ws}}-\mathrm{X}_{\mathrm{ss}}} \dot{\mathrm{m}}_{\mathrm{r}}$

Energy equation for major parts of single effect absorption chiller (such as generator, condenser, absorber and evaporator) may be written as follows:

Generator:

$\dot{\mathrm{m}}_{11} \mathrm{~h}_{11}+\dot{\mathrm{m}}_{3} \mathrm{~h}_{3}-\dot{\mathrm{m}}_{7} \mathrm{~h}_{7}-\dot{\mathrm{m}}_{4} \mathrm{~h}_{4}-\dot{\mathrm{m}}_{12} \mathrm{~h}_{12}=0$

Condenser:

$\dot{\mathrm{m}}_{15} \mathrm{~h}_{15}+\dot{\mathrm{m}}_{7} \mathrm{~h}_{7}-\dot{\mathrm{m}}_{8} \mathrm{~h}_{8}-\dot{\mathrm{m}}_{16} \mathrm{~h}_{16}=0$

Absorber:

$\dot{\mathrm{m}}_{10} \mathrm{~h}_{10}+\dot{\mathrm{m}}_{13} \mathrm{~h}_{13}+\dot{\mathrm{m}}_{6} \mathrm{~h}_{6}-\dot{\mathrm{m}}_{1} \mathrm{~h}_{1}-\dot{\mathrm{m}}_{14} \mathrm{~h}_{14}=0$

Evaporator:

$\dot{\mathrm{m}}_{9} \mathrm{~h}_{9}+\dot{\mathrm{m}}_{18} \mathrm{~h}_{18}-\dot{\mathrm{m}}_{17} \mathrm{~h}_{17}-\dot{\mathrm{m}}_{10} \mathrm{~h}_{10}=0$

The fluid of flow through expansion valves is an isenthalpic process. So enthalpy will be constant.

$h_{8}=h_{9}$

$\mathrm{h}_{5}=\mathrm{h}_{6}$

Often effectiveness may be used to evaluate heat exchangers as follows:

$\varepsilon=\frac{T_{2}-T_{3}}{T_{2}-T_{4}}=\frac{T_{4}-T_{5}}{T_{4}-T_{2}}$
COP of a single effect absorption chiller may be defined as follows:

$\mathrm{COP}=\frac{\dot{\mathrm{m}}_{\mathrm{CHW}}\left(\mathrm{h}_{18}-\mathrm{h}_{17}\right)}{\dot{\mathrm{m}}_{\mathrm{HS}}\left(\mathrm{h}_{11}-\mathrm{h}_{12}\right)+\dot{\mathrm{W}}_{\mathrm{p}}}$

It is essential to evaluate the enthalpy of $\mathrm{LiBr}$ solution. This may be done by the following equation [19]:

$h_{L i B r}=\sum_{n=0}^{n=4} L_{n} X^{n}+T_{s} \sum_{n=0}^{n=4} M_{n} X^{n}+T_{s}^{2} \sum_{n=0}^{n=4} N_{n} X^{n}$

\begin{tabular}{llll}
\hline $\mathrm{i}$ & $\mathrm{L}_{\mathrm{i}}$ & $\mathrm{M}_{\mathrm{i}}$ & $\mathrm{N}_{\mathrm{i}}$ \\
\hline 0 & -2024.33 & 18.2829 & $-3.7008214 \mathrm{E}-2$ \\
1 & 163.309 & -1.1691757 & $2.8877666 \mathrm{E}-3$ \\
2 & -4.88161 & $3.248041 \mathrm{E}-2$ & $-8.1313015 \mathrm{E}-5$ \\
3 & $6.302948 \mathrm{E}-2$ & $-4.034184 \mathrm{E}-4$ & $9.9116628 \mathrm{E}-7$ \\
4 & $-2.913705 \mathrm{E}-4$ & $1.8520569 \mathrm{E}-6$ & $-4.4441207 \mathrm{E}-9$ \\
\hline
\end{tabular}

To analyse the thermodynamic model, a Matlab code is developed. So it is required to have the enthalpy and the entropy equations of the water. To evaluate the enthalpy of super-heated steam, thermodynamics tables are applied. These data may be shown as Eq. (18) by using genetic algorithm and by minimizing error between the calculated and the measured data:

$h_{H S}=\left(a_{1} T^{a_{2}}+a_{3}\right)\left(a_{4} T^{a_{5}}+a_{6}\right)$

\begin{tabular}{lll}
\hline $\mathrm{a}_{1}=1.34437672$ & $\mathrm{a}_{2}=1.0636647$ & $\mathrm{a}_{3}=-2058.09$ \\
500784 & 9289381 & 317323101 \\
$\mathrm{a}_{4}=6316.190026$ & $\mathrm{a}_{5}=-0.0006973622$ & $\mathrm{a}_{6}=-1741$. \\
72389 & 32285187 & 36346240702 \\
\hline
\end{tabular}

The above equation is valid for $46 C<T<200 C$ and $10 \mathrm{kpa}<p<200 \mathrm{kpa}$. The comparison between the

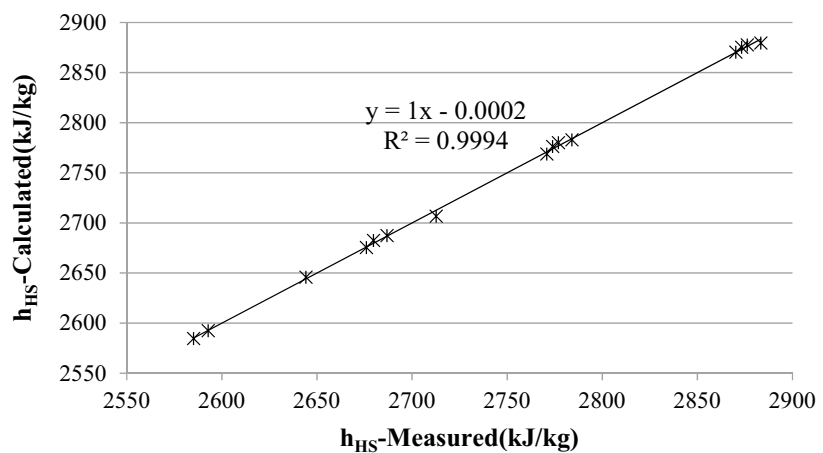

Fig. 2 Calculated enthalpy VS. measured enthalpy for super-heated steam 
calculated and the measured enthalpy of super-heated steam is shown in Fig. 2.

Enthalpy of saturated water may be written as follows by using genetic algorithm and by minimizing error between the calculated and the measured data:

$\mathrm{h}_{\text {sat.,water }}=\left(\mathrm{a}_{7} \mathrm{~T}^{\mathrm{a}_{8}}+\mathrm{a}_{9}\right)\left(\mathrm{a}_{10} \mathrm{~T}^{\mathrm{a}_{11}}+\mathrm{a}_{12}\right)$

\begin{tabular}{lll}
\hline $\mathrm{a}_{7}=4.2507554$ & $\mathrm{a}_{8}=0.995768$ & $\mathrm{a}_{9}=0.6663$ \\
1441917 & 160932023 & 56232217841 \\
$\mathrm{a}_{10}=0.047134871$ & $\mathrm{a}_{11}=0.8374314$ & $\mathrm{a}_{12}=-0.7844$ \\
3699375 & 02908669 & 85525587839 \\
\hline
\end{tabular}

The above equation is valid for $0 C<T<120 C$ and $0.6 \mathrm{kpa}<p<195 \mathrm{kpa}$. The comparison between the calculated and the measured enthalpy of saturated water is shown in Fig. 3.

Enthalpy of saturated steam may be given by:

$\mathrm{h}_{\text {sat.,steam }}=\left(\mathrm{a}_{13} \mathrm{~T}^{\mathrm{a}_{14}}+\mathrm{a}_{15}\right)\left(\mathrm{a}_{16} \mathrm{~T}^{\mathrm{a}_{17}}+\mathrm{a}_{18}\right)$

\begin{tabular}{lll}
\hline $\mathrm{a}_{13}=15.69123$ & $\mathrm{a}_{14}=-0.004865766$ & $\mathrm{a}_{15}=1790.96$ \\
76003977 & 7363225 & 521687448 \\
$\mathrm{a}_{16}=257.87843$ & $\mathrm{a}_{17}=0.10560011$ & $\mathrm{a}_{18}=449.5705$ \\
5466569 & 4164934 & 79620051 \\
\hline
\end{tabular}

The above equation is valid for $0 C<T<120 C$ and $0.6 \mathrm{kpa}<p<195 \mathrm{kpa}$. The comparison between calculated and measured enthalpy of saturated steam is shown in Fig. 4.

Also the enthalpy of sub cooled water may be calculated from the enthalpy equation of saturated water. The temperature of sub-cooled water can be calculated by applying its related enthalpy and the pressure as follows:

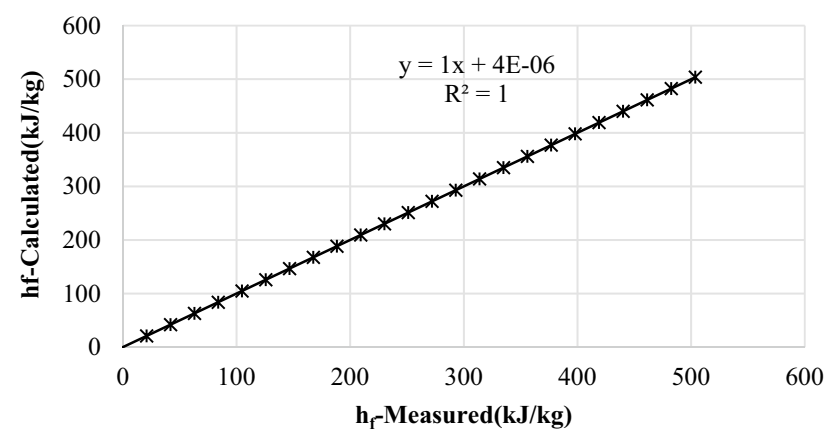

Fig. 3 Calculated enthalpy VS. measured enthalpy for saturated water

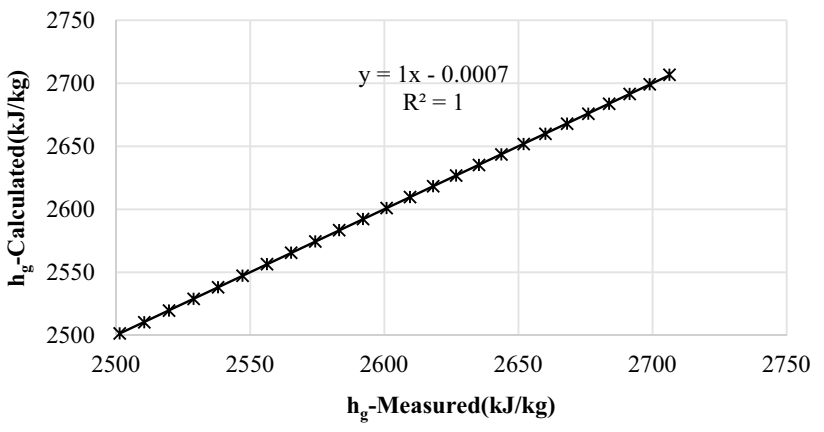

Fig. 4 Calculated enthalpy VS. measured enthalpy for saturated steam

$T=\left(\frac{h / a_{7}}{a_{10} p^{a_{11}}+a_{12}}-\frac{a_{9}}{a_{7}}\right)^{\frac{1}{a_{8}}}$

The second law of thermodynamics may be applied to evaluate the entropy generation. The law, states that the entropy variation is not negative in the insulated system. In fact entropy is a criterion to evaluate irreversibility. The system may be optimized from the engineering point of view and the thermodynamic operation can be improved by minimizing the entropy generation. The general equation to evaluate entropy generation can be written by [20]:

$\mathrm{S}_{\text {gen. }}=\sum_{\text {out }} \dot{\mathrm{m} s}-\sum_{\text {in }} \dot{\mathrm{m} s}$

Entropy generation may be evaluated for major parts of absorption chiller by applying the Eq. (22):

Generator:

$\mathrm{S}_{\mathrm{g}}=\dot{\mathrm{m}}_{7} \mathrm{~s}_{7}+\dot{\mathrm{m}}_{4} \mathrm{~s}_{4}-\dot{\mathrm{m}}_{3} \mathrm{~s}_{3}+\dot{\mathrm{m}}_{11}\left(\mathrm{~s}_{12} \mathrm{~s}_{11}\right)$

Condenser:

$\mathrm{S}_{\mathrm{c}}=\dot{\mathrm{m}}_{7}\left(\mathrm{~s}_{8}-\mathrm{s}_{7}\right)+\dot{\mathrm{m}}_{15}\left(\mathrm{~s}_{16}-\mathrm{s}_{15}\right)$

Absorber:

$\mathrm{s}_{\mathrm{a}}=\dot{\mathrm{m}}_{1} \mathrm{~s}_{1}-\dot{\mathrm{m}}_{10} \mathrm{~s}_{10}-\dot{\mathrm{m}}_{6} \mathrm{~s}_{6}+\dot{\mathrm{m}}_{13}\left(\mathrm{~s}_{14}-\mathrm{s}_{13}\right)$

Evaporator:

$$
\mathrm{S}_{\mathrm{e}}=\dot{\mathrm{m}}_{9}\left(\mathrm{~s}_{10}-\mathrm{s}_{9}\right)+\dot{\mathrm{m}}_{17}\left(\mathrm{~s}_{17}-\mathrm{s}_{18}\right)
$$

So the entropy generation of single effect absorption chiller may be calculated by the following expression:

$\mathrm{S}_{\mathrm{abs}, \text {, hiller }}=\mathrm{S}_{\mathrm{g}}+\mathrm{S}_{\mathrm{c}}+\mathrm{S}_{\mathrm{a}}+\mathrm{S}_{\mathrm{e}}$ 
To evaluate the entropy of super-heated steam, thermodynamic data would be applied. These data may be written as the following formula by using genetic algorithm and by minimizing error between the calculated and the measured data:

$s_{H S}=\left(b_{1} T^{b_{2}}+b_{3}\right)\left(b_{4} T^{b_{5}}+b_{6}\right)$

\begin{tabular}{lll}
\hline $\mathrm{b}_{1}=0.0183083$ & $\mathrm{~b}_{2}=0.776431$ & $\mathrm{~b}_{3}=-54.680$ \\
42545615 & 743136796 & 1821097401 \\
\hline $\mathrm{b}_{4}=222.7083$ & $\mathrm{~b}_{5}=-0.0021266$ & $\mathrm{~b}_{6}=-159.1$ \\
21981383 & 2182407585 & 4714450636 \\
\hline
\end{tabular}

The comparison between the calculated and the measured entropy of super-heated steam is shown in Fig. 5.

The entropy of saturated water may be written as follows:

$s_{\text {sat., water }}=\left(b_{7} T^{b_{8}}+b_{9}\right)\left(b_{10} T^{b_{11}}+b_{12}\right)$

\begin{tabular}{lll}
\hline $\mathrm{b}_{7}=0.00647809$ & $\mathrm{~b}_{8}=0.9873167$ & $\mathrm{~b}_{9}=-4.8407$ \\
527094119 & 29289612 & 1962904189 \\
$\mathrm{~b}_{10}=4.0569$ & $\mathrm{~b}_{11}=0.0314$ & $\mathrm{~b}_{12}=0.84580$ \\
2825941513 & 263248450064 & 8766192197 \\
\hline
\end{tabular}

The comparison between the calculated and the measured entropy of saturated water is shown in Fig. 6.

The entropy of saturated steam may be given by:

$s_{\text {sat.steam }}=\left(b_{13} T^{b_{14}}+b_{15}\right)\left(b_{16} T^{b_{17}}+b_{18}\right)$

\begin{tabular}{lll}
\hline$b_{13}=0.00011583$ & $b_{14}=0.947356$ & $b_{15}=1.0567141$ \\
0766898754 & 058095848 & 0322986 \\
$b_{16}=20.90393$ & $b_{17}=-0.0175695$ & $b_{18}=-12.985$ \\
67183081 & 377669539 & 8906826755 \\
\hline
\end{tabular}

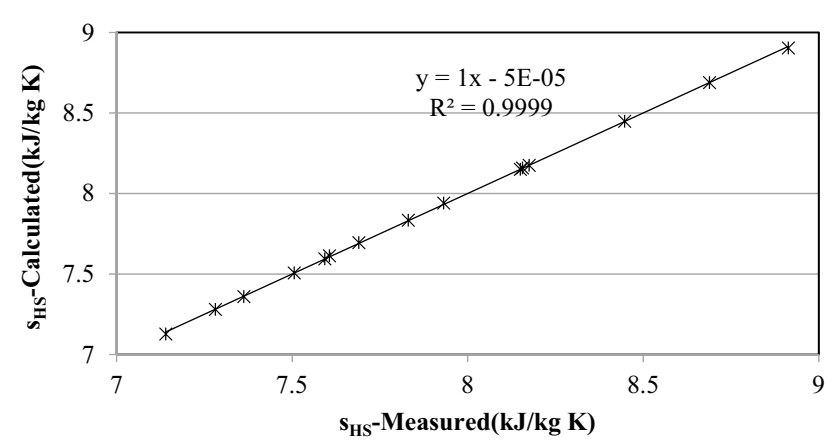

Fig. 5 Calculated entropy VS. measured entropy for super-heated steam

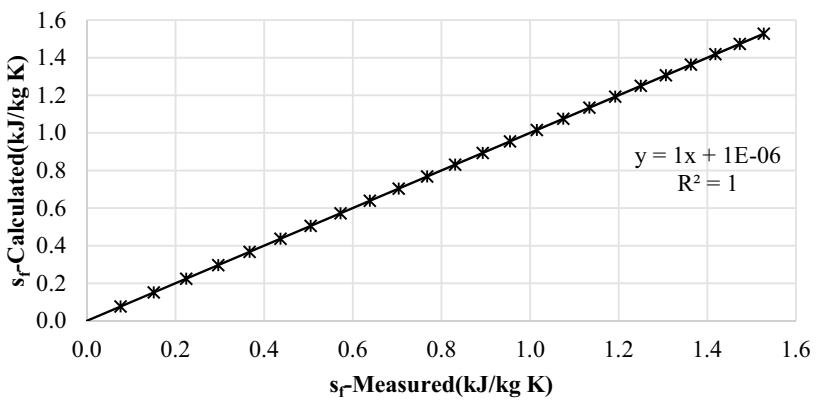

Fig. 6 Calculated entropy VS. measured entropy for saturated water

The comparison between the calculated and the measured entropy of saturated steam is shown in Fig. 7.

The temperature and the pressure range of Eqs. (28) to (30) are equal to the temperature and pressure ranges of Eq. (18) to (20). Also entropy of sub-cooled water may be calculated as follows:

$\mathrm{S}_{\text {sub-cooled water }}=0.2966+4.184 \ln \left(\frac{\mathrm{T}+273.15}{293.15}\right)$

Entropy of the lithium Bromide-water solution may be calculated through the following equation [21]:

$$
\begin{aligned}
s_{L i B r}= & -\left(A_{0}+A_{1} X+A_{2} X^{2}+A_{3} X^{3}+A_{4} X^{1.1}\right) \\
& -2\left(T_{s}+273.15\right)\left(B_{0}+B_{1} X+B_{2} X^{2}+B_{3} X^{3}+B_{4} X^{1 \cdot 1}\right) \\
& -3\left(T_{s}+273.15\right)^{2}\left(C_{0}+C_{1} X+C_{2} X^{2}+C_{3} X^{3}+C_{4} X^{1.1}\right) \\
& -4\left(T_{s}+273.15\right)^{3}\left(D_{0}+D_{1} X\right)+\frac{E_{0}+E_{1} X}{\left(T_{s}-T_{0}\right)^{2}} \\
& -p\left(F_{0}+F_{1} X+F_{2} X^{2}+2 F_{3}\left(T_{s}+273.15\right)+2 F_{4} X\left(T_{s}+273.15\right)\right) \\
& -\frac{1}{\left(T_{s}+273.15\right)}\left(G_{0}+G_{1} X+G_{2} X^{2}+G_{3} X^{3}+G_{4} X^{1.1}\right) \\
& -\left(1+\ln \left(T_{s}+273.15\right)\right)\left(H_{0}+H_{1} X+H_{2} X^{2}+H_{3} X^{3}+H_{4} X^{1.1}\right)
\end{aligned}
$$

\begin{tabular}{lllll}
\hline $\mathrm{i}$ & $\mathrm{A}_{\mathrm{i}}$ & $\mathrm{B}_{\mathrm{i}}$ & $\mathrm{C}_{\mathrm{i}}$ & $\mathrm{D}_{\mathrm{i}}$ \\
\hline 0 & 1.452749 & 2.64836 & -8.5265 & -3.8404 \\
& $674 \mathrm{E} 2$ & $4473 \mathrm{E}-2$ & $16950 \mathrm{E}-6$ & $47174 \mathrm{E}-11$
\end{tabular}

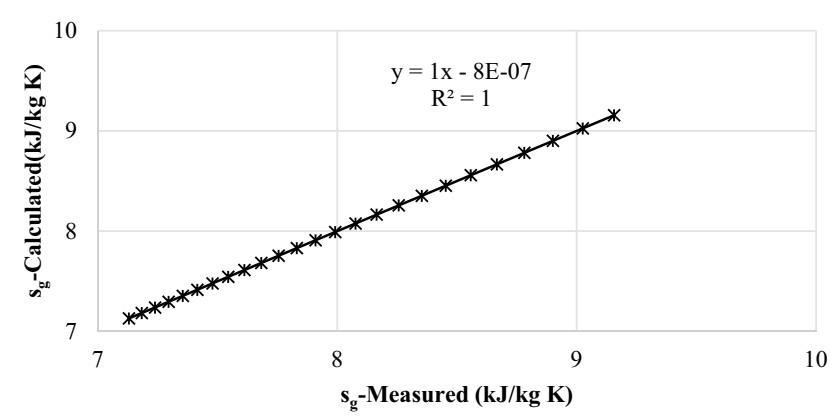

Fig. 7 Calculated entropy VS. measured entropy for saturated steam 


\begin{tabular}{lllll}
\hline $\mathrm{i}$ & $\mathrm{A}_{\mathrm{i}}$ & $\mathrm{B}_{\mathrm{i}}$ & $\mathrm{C}_{\mathrm{i}}$ & $\mathrm{D}_{\mathrm{i}}$ \\
\hline 1 & -4.9848 & -2.3110 & 1.32015 & 2.62546 \\
& $40771 \mathrm{E}-1$ & $41091 \mathrm{E}-3$ & $4794 \mathrm{E}-6$ & $9387 \mathrm{E}-11$ \\
2 & 8.83691 & 7.559736 & 2.79199 & 0 \\
& $9180 \mathrm{E}-2$ & $620 \mathrm{E}-6$ & $5438 \mathrm{E}-11$ & \\
3 & -4.870 & -3.7639 & 0 & 0 \\
& $995781 \mathrm{E}-4$ & $34193 \mathrm{E}-8$ & & \\
4 & -2.905 & 1.176 & -8.511 & 0 \\
& 161205 & 2406 & $514931 \mathrm{E}-7$ & \\
& & $49 \mathrm{E}-3$ & & \\
\hline
\end{tabular}

\begin{tabular}{lllll}
\hline $\mathrm{i}$ & $\mathrm{E}_{\mathrm{i}}$ & $\mathrm{F}_{\mathrm{i}}$ & $\mathrm{G}_{\mathrm{i}}$ & $\mathrm{H}_{\mathrm{i}}$ \\
\hline 0 & -5.159 & -1.497 & -2.18 & -2.2670 \\
& $906276 \mathrm{E} 1$ & 1869 & 342 & $95847 \mathrm{E} 1$ \\
& & $05 \mathrm{E}-6$ & $9482 \mathrm{E} 3$ & \\
1 & 1.114 & 2.5381 & -1.2669 & 2.9837 \\
& 573398 & $76345 \mathrm{E}-8$ & $85094 \mathrm{E} 2$ & $64494 \mathrm{E}-1$ \\
2 & 0 & 5.81581 & -2.36 & -1.2593 \\
& & $1591 \mathrm{E}-11$ & 4551372 & $93234 \mathrm{E}-2$ \\
3 & 0 & 3.05799 & 1.38 & 6.8496 \\
& & $7846 \mathrm{E}-9$ & $9414858 \mathrm{E}-2$ & $32068 \mathrm{E}-5$ \\
4 & 0 & -5.12958 & 1.5834 & 2.7679 \\
& & $9007 \mathrm{E}-11$ & $05426 \mathrm{E} 2$ & $86853 \mathrm{E}-1$
\end{tabular}

Table 1 Process data of chiller [22]

\begin{tabular}{lllllc}
\hline Point & $\mathrm{T}(\mathrm{C})$ & $\mathrm{h}(\mathrm{kJ} / \mathrm{kg})$ & $\mathrm{s}(\mathrm{kJ} / \mathrm{kg} \mathrm{K})$ & $\mathrm{X}(\%)$ & $\dot{\mathrm{m}}(\mathrm{kg} / \mathrm{s})$ \\
\hline 1 & 40 & 107.1 & 0.2379 & 55.2 & 5.81 \\
2 & 40 & 107.1 & 0.2379 & 55.2 & 5.81 \\
3 & 67 & 160.5 & 0.3986 & 55.2 & 5.81 \\
4 & 81 & 202.7 & 0.45 & 60.64 & 5.31 \\
5 & 55 & 153.8 & 0.3087 & 60.64 & 5.31 \\
6 & 41 & 153.8 & 0.3087 & 60.64 & 5.31 \\
7 & 73.36 & 2632 & 8.6 & 0 & 0.5 \\
8 & 34 & 142.4 & 0.5579 & 0 & 0.5 \\
9 & 5 & 142.4 & 0.07 & 0 & 0.5 \\
10 & 5 & 2510.21 & 9.026 & 0 & 0.5 \\
11 & 115 & 2699.18 & 7.18 & 0 & 0.65 \\
12 & 95 & 398 & 1.35 & 0 & 0.65 \\
13 & 28 & 117.3 & 0.41 & 0 & 70.92 \\
14 & 33 & 138.2 & 0.48 & 0 & 70.92 \\
15 & 28 & 117.3 & 0.41 & 0 & 59.97 \\
16 & 32 & 134 & 0.48 & 0 & 59.97 \\
17 & 9 & 37.8 & 0.14 & 0 & 56.42 \\
18 & 14 & 58.73 & 0.21 & 0 & 56.42 \\
\hline
\end{tabular}

Table 2 Comparison between the current calculated data and the measured results by Panahizadeh and Bozorgan [22]

\begin{tabular}{lcl}
\hline Parameter & $\mathrm{Q}_{\text {calculated }}(\mathrm{kW})$ & $\begin{array}{l}\mathrm{Q}_{\text {measured }} \\
(\mathrm{kW})[22]\end{array}$ \\
\hline Generator & 1980.3 & 1910 \\
Evaporator & 1330.2 & 1360 \\
Absorber & 1863.1 & 1878 \\
Condenser & 918.3 & 920.4 \\
\hline
\end{tabular}

$\mathrm{T}_{0}=220 \mathrm{~K}$

$\mathrm{T}_{0}=220 \mathrm{~K}$ was arrived by iteration outside the linear coefficient calculations [21].

\section{Evaluation of an absorption chiller}

To analyze the chiller, the heat exchanger effectiveness is assumed to be 0.7 and the mass flow rate of refrigerant is $0.5 \mathrm{~kg} / \mathrm{s}$. The water steam enters to the generator at $115 \mathrm{C}$ and leaves it at $95 \mathrm{C}$. Also the solution pump has ignorable effect on the solution temperature and the absorber and the condenser temperatures are the same. Process data of the chiller is shown in Table 1 [22].

The current results were compared with the data which is presented by Panahizadeh and Bozorgan [22]. The corresponding calculated values are presented in Table 2. A good agreement can be observed with the maximum discrepancy in heat transfer rate lying 3.6\% of the data of Panahizadeh and Bozorgan [22].

\subsection{Effect of the generator temperature on entropy generation and COP}

Generator temperature effect on the entropy generation and COP is shown in the Fig. 8 for various $T_{c}$ and $T_{e}$. At the beginning, entropy generation would be decreased rapidly by increasing generator temperature and in the following, the entropy generation is approximately constant. Also the minimum entropy generation may be decreased by decreasing $T_{c}$ and the entropy generation for each $T_{c}$ and $T_{g}$ may be decreased by increasing Te. Also at the beginning, the COP is increased rapidly but after a while the COP will be constant. The maximum amount of COP is decreased by increasing $T_{c}$ and COP is increased by increasing $T_{e}$ for each $T_{g}$ and $T_{c}$.

In this study the optimum generator temperature is defined as the temperature that $S_{\text {gen. }}$ is the minimum and COP is the maximum. In the lower $T_{C}$, the maximum COP 


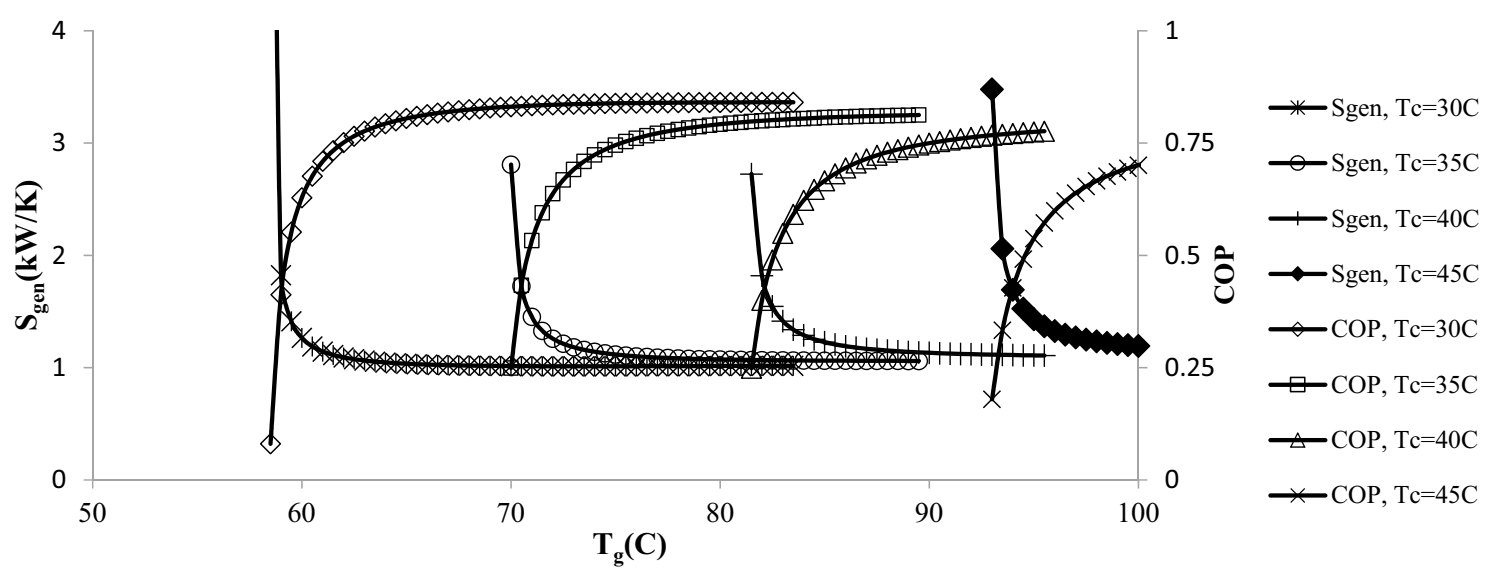

(a)

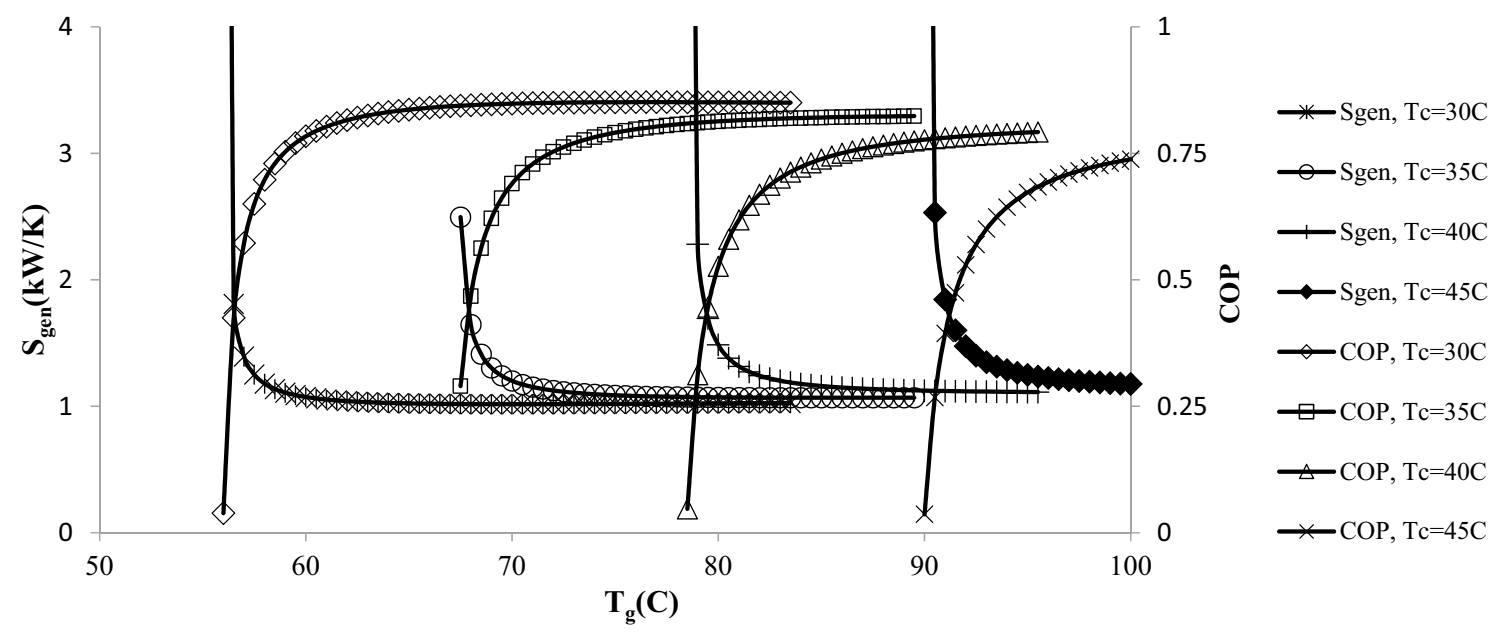

(b)

Fig. 8 Generator temperature VS. $S_{g}$ and $\operatorname{COP}(a) T_{e}=3 C$ and (b) $T_{e}=7 C$

Fig. 9 Schematic of internal combustion engine with turbocharger

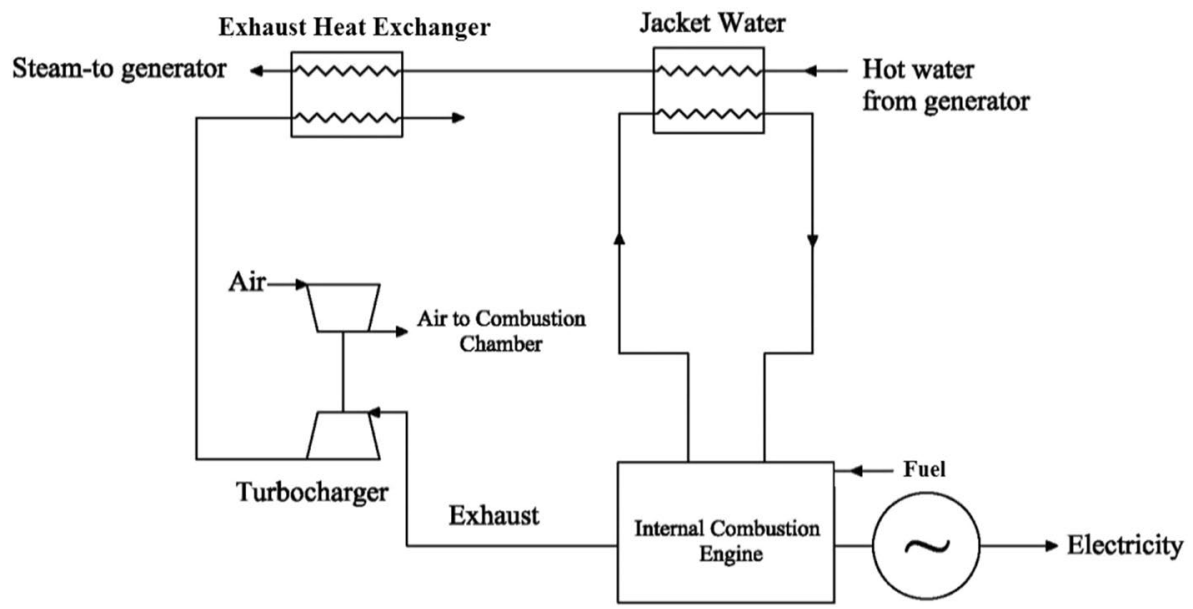

and the minimum Sgen. are in a specific Tg and there is insignificant change by increasing generator temperature.
It means there is no need to increase Tg, so energy consumption would be optimized. 


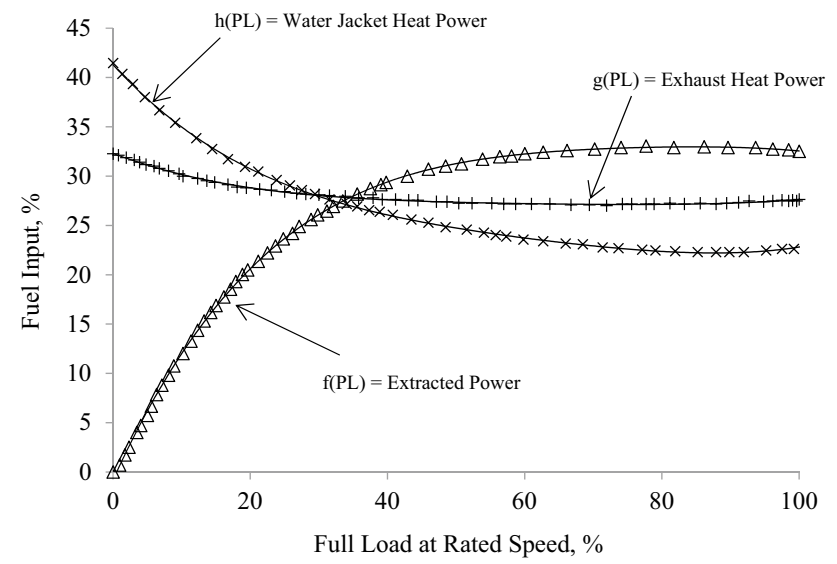

Fig. 10 Equations of internal combustion engine VS. partial load [23]

Table 3 Building specifications [25]

\begin{tabular}{ll}
\hline Item & Description \\
\hline Average occupancy (Person) & 5 \\
Number of floors & 10 \\
Walls' overall U-value $\left(\mathrm{W} / \mathrm{m}^{2} / \mathrm{K}\right)$ & 2.14 \\
Roofs' overall U-value $\left(\mathrm{W} / \mathrm{m}^{2} / \mathrm{K}\right)$ & 0.33 \\
Windows' overall U-value $\left(\mathrm{W} / \mathrm{m}^{2} / \mathrm{K}\right)$ & 6.4 \\
Doors' overall U-value $\left(\mathrm{W} / \mathrm{m}^{2} / \mathrm{K}\right)$ & 1.7 \\
Floor' overall U-value for first floors $\left(\mathrm{W} / \mathrm{m}^{2} / \mathrm{K}\right)$ & 0.568 \\
Lightings $(\mathrm{kW})$ & 0.75 \\
\hline
\end{tabular}

\section{Prime mover}

In the current manuscript, internal combustion engine is applied to provide heating demand of the chiller. The schematic of an internal combustion engine may be shown as Fig. 9.

Since prime movers may not work in the full load for a long time, so the partial load operation is studied here. To analyse the extracted heating power of the engine, the existing graph [23] is applied. The related output heating and the power may be calculated through this graph (Fig. 10) and Eqs. (33)-(37).

$$
\begin{aligned}
f(P L)= & \frac{\dot{E}_{P M, P L}}{\dot{m}_{f} L H V_{f}}=(-7.28 E-07)(P L)^{4}+0.000225(P L)^{3} \\
& -0.02724(P L)^{2}+1.530561(P L)-0.80065 \\
g(P L)= & \frac{\dot{Q}_{E x, P L}}{\dot{m}_{f} L H V_{f}}=(2.182 E-07)(P L)^{4}-(5.527 E-05)(P L)^{3} \\
& +0.005517(P L)^{2}-0.26403345(P L)+32.3062
\end{aligned}
$$

Table 4 Monthly cooling load of the tower in Tehran (kW) [25]

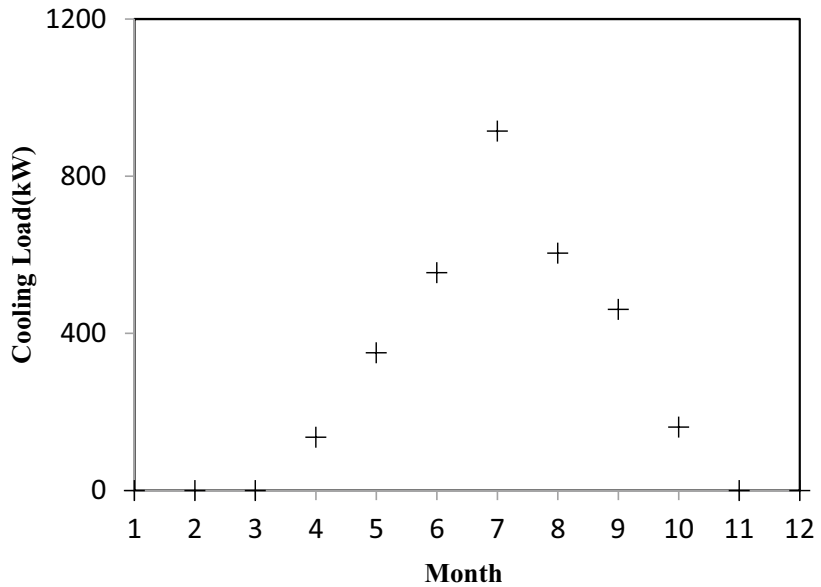

Fig. 11 Cooling load variation for Tehran [25]

$$
\begin{aligned}
h(P L)= & \frac{\dot{Q}_{W J . P L}}{\dot{m}_{f} L H V_{f}}=(5.657 E-07)(P L)^{4}-0.000141494(P L)^{3} \\
& +0.014249421(P L)^{2}-0.760595(P L)+41.294
\end{aligned}
$$

$\mathrm{J}(\mathrm{PL})=\frac{\dot{\mathrm{m}}_{\mathrm{f}, \mathrm{PL}}}{\dot{\mathrm{m}}_{\mathrm{f}, \text { nom. }}}=-0.02836 \exp (0.03254(\mathrm{PL}))$

$+0.2556 \exp (0.01912(\mathrm{PL}))[24]$

$\dot{\mathrm{m}}_{\mathrm{f}, \text { nom. }}=\frac{\dot{\mathrm{E}}_{\mathrm{PM}}}{\eta_{\mathrm{PM}, \text { nom. }} \text { LHV }_{\mathrm{f}}}$

In the Fig. 10, "Fuel Input, \%" means the approximate percentage of input fuel energy $\left(\dot{m}_{f} L H V_{f}\right)$ would be changed to the engine power. 


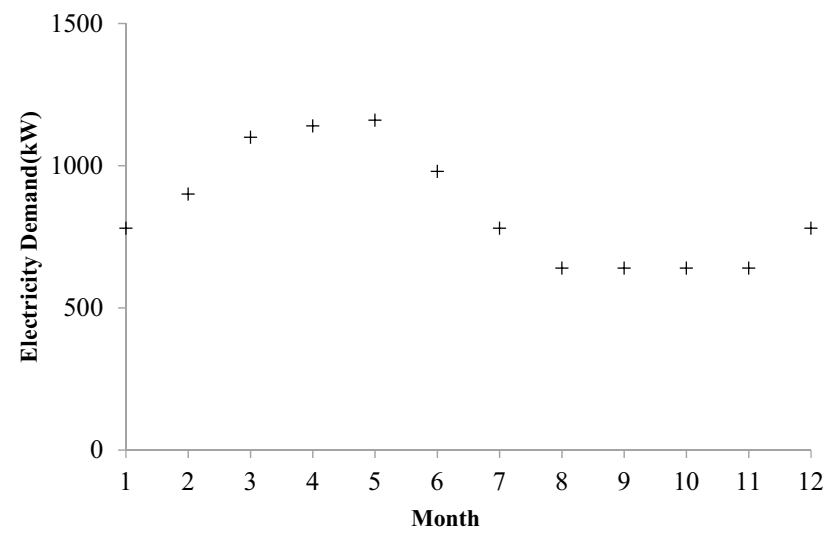

Fig. 12 Electrical demand variation of the considered tower [25]

Table 5 Power and heating load of a prime mover in partial load $\left(\dot{\mathrm{E}}_{\mathrm{PM}, \text { nom. }}=400 \mathrm{~kW}\right)$

\begin{tabular}{llll}
\hline $\mathrm{PL}(\%)$ & $\dot{\mathrm{E}}_{\mathrm{p}}(\mathrm{kW})$ & $\dot{\mathrm{Q}}_{\text {Exhaust }}(\mathrm{kW})$ & $\dot{\mathrm{Q}}_{\mathrm{WJ}}(\mathrm{kW})$ \\
\hline 20 & 81.2 & 113.6 & 121.2 \\
40 & 161 & 151.1 & 142.7 \\
60 & 240.1 & 202.7 & 176.7 \\
80 & 323 & 266.1 & 219.3 \\
100 & 399.6 & 338.3 & 279.3 \\
\hline
\end{tabular}

\section{Cooling and electrical loads [25]}

In tis study, a 10 story residential tower is considered which is used by Mohammadian Korouyeh et al. [25]. The length and the width of the tower are 40 and $20 \mathrm{~m}$ respectively and the height of each unit is $3 \mathrm{~m}$. The northern and the southern windows are $30 \%$ of the wall surface area and both the western and eastern windows are $20 \%$. The other detailed information is tabulated in Table 3.

The cooling load is calculated for the first, central and the last floors and these loads are summed up to calculate the tower loads. Table 4 shows the cooling load data of the tower. Tehran city has been selected as the representative city of hot-dry weather condition. These data may be shown in Fig. 11 too.

It is required to estimate the electrical demand of the building to select the proper number of the prime movers. The electrical load of the building is shown in Fig. 12.

\section{Providing heating demand of the generator}

The criterion of selecting the prime mover is the maximum electrical load. Since the maximum electrical demand is $1160 \mathrm{~kW}$, so four prime movers with the nominal capacity of $400 \mathrm{~kW}$ are provided. Low heating value (LHV) of natural
Table 6 Optimum $\mathrm{S}_{\text {gen. }}$ and the related $\mathrm{T}_{\mathrm{g}}$

\begin{tabular}{|c|c|c|c|c|c|c|c|c|c|c|c|c|}
\hline & \multicolumn{4}{|c|}{$\mathrm{T}_{\mathrm{ev} .}=3 \mathrm{C}$} & \multicolumn{4}{|c|}{$\mathrm{T}_{\mathrm{ev} .}=5 \mathrm{C}$} & \multicolumn{4}{|c|}{$\mathrm{T}_{\mathrm{ev} .}=7 \mathrm{C}$} \\
\hline & \multicolumn{4}{|l|}{$\mathrm{T}_{\mathrm{c}}(\mathrm{C})$} & \multicolumn{4}{|c|}{$\mathrm{T}_{\mathrm{c}}(\mathrm{C})$} & \multicolumn{4}{|l|}{$\mathrm{T}_{\mathrm{c}}(\mathrm{C})$} \\
\hline & 30 & 35 & 40 & 45 & 30 & 35 & 40 & 45 & 30 & 35 & 40 & 45 \\
\hline $\mathrm{S}_{\text {gen, opt. }}(\mathrm{kW} / \mathrm{K})$ & 1.07 & 1.13 & 1.18 & 1.26 & 1.06 & 1.12 & 1.17 & 1.21 & 1.05 & 1.12 & 1.17 & 1.21 \\
\hline $\mathrm{T}_{\mathrm{g}, \mathrm{opt} .}(\mathrm{C})$ & 66 & 77.5 & 89.5 & 100 & 63 & 75 & 87 & 99 & 60.5 & 72 & 84 & 96 \\
\hline
\end{tabular}

\begin{tabular}{|c|c|c|c|c|c|c|c|c|c|c|c|c|}
\hline & \multicolumn{4}{|c|}{$\mathrm{T}_{\mathrm{ev} .}=3 \mathrm{C}$} & \multicolumn{4}{|c|}{$\mathrm{T}_{\mathrm{ev} .}=5 \mathrm{C}$} & \multicolumn{4}{|c|}{$\mathrm{T}_{\mathrm{ev} .}=7 \mathrm{C}$} \\
\hline & \multicolumn{4}{|l|}{$\mathrm{T}_{\mathrm{c}}(\mathrm{C})$} & \multicolumn{4}{|l|}{$\mathrm{T}_{\mathrm{c}}(\mathrm{C})$} & \multicolumn{4}{|l|}{$\mathrm{T}_{\mathrm{c}}(\mathrm{C})$} \\
\hline & 30 & 35 & 40 & 45 & 30 & 35 & 40 & 45 & 30 & 35 & 40 & 45 \\
\hline $\mathrm{COP}_{\text {opt. }}$ & 0.76 & 0.73 & 0.70 & 0.63 & 0.78 & 0.74 & 0.71 & 0.68 & 0.80 & 0.75 & 0.71 & 0.69 \\
\hline $\mathrm{T}_{\mathrm{g}, \mathrm{opt} .}(\mathrm{C})$ & 65.5 & 77.5 & 89.5 & 100 & 63 & 74.5 & 86.5 & 98.5 & 60.5 & 72 & 83.5 & 95.5 \\
\hline
\end{tabular}

Table 7 Optimum COP and the related $\mathrm{T}_{\mathrm{g}}$

Table $8 \mathrm{Q}_{\mathrm{g}}$ related to the maximum $\mathrm{T}_{\mathrm{g}}$ of Tables 5 and 6

\begin{tabular}{|c|c|c|c|c|c|c|c|c|c|c|c|c|}
\hline & \multicolumn{4}{|l|}{$\mathrm{T}_{\mathrm{ev} .}=3 \mathrm{C}$} & \multicolumn{4}{|c|}{$\mathrm{T}_{\mathrm{ev} .}=5 \mathrm{C}$} & \multicolumn{4}{|c|}{$\mathrm{T}_{\mathrm{ev} .}=7 \mathrm{C}$} \\
\hline & \multicolumn{4}{|l|}{$\mathrm{T}_{\mathrm{c}}(\mathrm{C})$} & \multicolumn{4}{|l|}{$\mathrm{T}_{\mathrm{c}}(\mathrm{C})$} & \multicolumn{4}{|l|}{$\mathrm{T}_{\mathrm{c}}(\mathrm{C})$} \\
\hline & 30 & 35 & 40 & 45 & 30 & 35 & 40 & 45 & 30 & 35 & 40 & 45 \\
\hline $\mathrm{Q}_{\mathrm{g}}(\mathrm{kW})$ & 1551.1 & 1622.9 & 1677.3 & 1833.3 & 1534.8 & 1585.2 & 1638.1 & 1692.4 & 1501.0 & 1568.4 & 1620.1 & 1673.9 \\
\hline$T_{g}(C)$ & 66 & 77.5 & 89.5 & 100 & 63 & 75 & 87 & 99 & 60.5 & 72 & 84 & 96 \\
\hline
\end{tabular}


Table 9 The required prime movers in the hottest month of the year Tehran

\begin{tabular}{|c|c|c|c|c|c|c|c|c|c|c|c|c|c|}
\hline & \multirow{2}{*}{\multicolumn{4}{|c|}{$\frac{\mathrm{T}_{\mathrm{ev} .}=3 \mathrm{C}}{\mathrm{T}_{\mathrm{c}}(\mathrm{C})}$}} & \multirow{2}{*}{\multicolumn{4}{|c|}{$\frac{\mathrm{T}_{\mathrm{ev} .}=5 \mathrm{C}}{\mathrm{T}_{\mathrm{c}}(\mathrm{C})}$}} & \multirow{2}{*}{\multicolumn{4}{|c|}{$\frac{\mathrm{T}_{\mathrm{ev}}=7 \mathrm{C}}{\mathrm{T}_{\mathrm{c}}(\mathrm{C})}$}} \\
\hline & & & & & & & & & & & & & \\
\hline & & 30 & 35 & 40 & 45 & 30 & 35 & 40 & 45 & 30 & 35 & 40 & 45 \\
\hline \multirow[t]{6}{*}{ PL (\%) } & $\mathrm{Q}_{\mathrm{g}, \mathrm{opt} .}(\mathrm{kW})$ & 1551 & 1622 & 1677 & 1833 & 1534 & 1585 & 1638 & 1692 & 1500 & 1568 & 1620 & 1673 \\
\hline & 20 & 7 & 7 & 7 & 8 & 7 & 7 & 7 & 7 & 6 & 7 & 7 & 7 \\
\hline & 40 & 5 & 6 & 6 & 6 & 5 & 5 & 6 & 6 & 5 & 5 & 6 & 6 \\
\hline & 60 & 4 & 4 & 4 & 5 & 4 & 4 & 4 & 4 & 4 & 4 & 4 & 4 \\
\hline & 80 & 3 & 3 & 3 & 4 & 3 & 3 & 3 & 3 & 3 & 3 & 3 & 3 \\
\hline & 100 & 3 & 3 & 3 & 3 & 2 & 3 & 3 & 3 & 2 & 3 & 3 & 3 \\
\hline
\end{tabular}

gas is equal to $49000 \frac{\mathrm{kJ}}{\mathrm{kg}}$ so nominal fuel mass flow rate is equal to $0.904 \frac{\mathrm{kg}}{\mathrm{hr}}$. By considering Eqs. (33)-(37), the extracted heating and the power of each prime mover may be shown in Table 5 for different partial loads.

In this study the $S_{\text {gen }}$ and the COP are selected as the objective functions. At the optimum situation, $\mathrm{S}_{\text {gen }}$ is the minimum and COP is the maximum. Tables 6 and 7 show related $\mathrm{T}_{\mathrm{g}}$ for $\mathrm{S}_{\text {gen.,opt. }}$ and $\mathrm{COP}_{\text {opt. }}$ for various $\mathrm{T}_{\mathrm{c}}$. Considering the maximum $T_{g}$ of Tables 6 and 7, the related $Q_{g}$ for each $\mathrm{T}_{c}$ is shown in Table 8.

Considering the $\mathrm{Q}_{g}$ of Table 8 , and the prime mover data in various partial loads (Table 5), the number of required prime movers is calculated and it is shown in Table 9.

\section{Conclusion}

In this study an analysis has been done for a single effect absorption chiller to find its optimum situation. A thermodynamic model has been developed from the first and the second laws of thermodynamics point of views to maximize the COP and minimize the entropy generation by considering permissible solution concentration range (between 0.5 to 0.65 ). The model is validated by the available data from the heat transfer rate point of view.

It has been found that entropy generation would be decreased by increasing the generator temperature whereas the COP is increased. The variations in the lower generator temperature are high while these variations are ignorable at higher generator temperatures. Also the minimum entropy generation may be decreased by increasing the evaporator temperature in each condensing and generator temperature but these variations are very low. To study the chiller entropy generation, it is recommended to consider only generator and condenser temperatures.

To provide required energy of generator, prime mover in the form of internal combustion engine is applied. A mathematical model is proposed to predict the performance of prime mover in partial load. In each evaporator and condensing temperature, the required prime movers are increased by decreasing the partial load. In each evaporator temperature and partial load, the required engines are increased or constant by increasing the condensing temperature.

The important limitation of the suggested system is its size which is essential to be compacted. Also for the future work, it is suggested to study the minimum entropy generation of the prime mover and the related parameters should be evaluated.

\section{Compliance with ethical standards}

Conflict of interest On behalf of all authors, the corresponding author states that there is no conflict of interest.

Open Access This article is licensed under a Creative Commons Attribution 4.0 International License, which permits use, sharing, adaptation, distribution and reproduction in any medium or format, as long as you give appropriate credit to the original author(s) and the source, provide a link to the Creative Commons licence, and indicate if changes were made. The images or other third party material in this article are included in the article's Creative Commons licence, unless indicated otherwise in a credit line to the material. If material is not included in the article's Creative Commons licence and your intended use is not permitted by statutory regulation or exceeds the permitted use, you will need to obtain permission directly from the copyright holder. To view a copy of this licence, visit http://creativecommons .org/licenses/by/4.0/.

\section{References}

1. Al-Sulaiman FA, Hamdullahpur F, Dincer I (2011) Trigeneration: a comprehensive review based on prime movers. Int J Energy Resour 35(3):233-258

2. Moussawi HA, Fardoun F, Louahlia-Gualous H (2016) Review of tri-generation technologies: design evaluation, optimization, decision-making, and selection approach. Energy Convers Manag 120:157-196

3. Chua H, Toh H, Malek A, Srinivasan K (2000) General thermodynamic frame work for understanding the behaviour of absorption chillers. Int J Refrig 23(7):491-507 
4. Avanessian T, Ameri M (2014) Energy, exergy and economic analysis of single and double effect $\mathrm{LiBr}-\mathrm{H}_{2} \mathrm{O}$ absorption chillers. Energy Build 73:26-36

5. Roman KK, Alvey JB (2016) Selection of prime mover for combined cooling, heating and power systems based on energy savings, life cycle analysis and environmental consideration. Energy Build 110:170-181

6. Fong KF, Lee CK (2014) Performance analysis of internal combustion engine primed trigeneration systems for use in high-rise office buildings in Hong Kong. In: The 6th International Conference on Applied Energy-ICAE2014

7. Karimi R, Sayyaadi H (2015) Optimal sizing of Stirling-CCHP systems for residential buildings at diverse climatic conditions. Appl Therm Eng 89:377-393

8. Ünal AN, Ersoz I, Kayakutlu G (2016) Operational optimization in simple tri-generation systems. Appl Therm Eng 107:175-183

9. Chahartaghi M, Alizadeh Kharkeshi B (2018) Performance analysis of a combined cooling, heating and power system with PEM fuel cell as a prime mover. Appl Therm Eng 128:805-817

10. Eisavi BE, Khalilarya S, Chitsaz A, Rosen MA (2018) Thermodynamic analysis of a novel combined cooling, heating and power system driven by solar energy. Appl Therm Eng 129:1219-1229

11. Ebrahimi M, Keshavarz A (2012) Climate impact on the prime mover size and design of a CCHP system for the residential building. Energy Build 54:283-289

12. Hojjat Mohammadi SM, Ameri M (2013) Energy and exergy analysis of a tri-generation water-cooled air conditioning system. Energy Build 67:453-462

13. Al-Solaiman FA, Hamdullahpour F, Dincer I (2012) Performance assessment of a novel system using parabolic trough solar collectors for combined cooling, heating, and power production. Renew Energy 48:161-172

14. Maindment GG, Tozer RM (2002) Combined cooling heat and power in supermarket. Appl Therm Eng 22:653-665
15. Samanta S, Basu DN (2016) Energy and entropy-based optimization of a single-stage water-lithium bromide absorption refrigeration system. Heat Transf Eng 37:232-241

16. Myat A, Thu K, Kim YD, Chakraborty A, Chun WG, Ng KC (2011) A second law analysis and entropy generation minimization of an absorption chiller. Appl Therm Eng 31:2405-2413

17. Ren J, Qian Z, Yao Z, Gan N, Zhang Y (2019) Thermodynamic evaluation of $\mathrm{LiCl}-\mathrm{H}_{2} \mathrm{O}$ absorption refrigeration systems based on a novel model and algorithm. Energies 12:1-30

18. Lansing FL (1976) Computer modeling of single-stage lithium bromide/water absorption refrigeration unit. Deep space network progress report, California

19. Muhumuza R (2010) Modeling, implementation and simulation of a single-effect absorption chiller in MERIT

20. Bejan A (2006) Advanced engineering thermodynamics, 3rd edn. Wiley, Hoboken

21. Yuan Z, Herold KE (2005) Thermodynamic properties of aqueous lithium bromide using a multiproperty free energy correlation. HVAC Res 11(3):377-393

22. Panahi Zadeh F, Bozorgan N (2011) The energy and exergy analysis of single effect absorption chiller. Int J Adv Des Manuf Technol 4:19-26

23. "COMBINED HEAT and POWER SYSTEMS," in Ashrae Handbook (2008)

24. Sanaye S, Meybodi M, Shokrollahi S (2008) Selecting the prime movers and nominal powers in combined heat and power systems. Appl Therm Eng 10:1177-1188

25. Mohammadian Korouyeh M, Saidi MH, Najafi M, Aghanajafi C (2019) Evaluation of desiccant wheel and prime mover as combined cooling, heating, and power system. Int J Green Energy $16: 256-268$

Publisher's Note Springer Nature remains neutral with regard to jurisdictional claims in published maps and institutional affiliations. 